\title{
WYBRANE KONCEPCJE REGIONU W SOCJOLOGII POLSKIEJ
}

\author{
SELECTED CONCEPTS OF THE REGION \\ IN POLISH SOCIOLOGY
}

\begin{abstract}
The aim of this article is to present the most important concepts of region in Polish sociology. After World War II the majority of sociological studies of regions were based on definitions which described the region as a private homeland of regional community that is integrated by regional identity. Such community lives in a territory which is a type of physical container for identity and culture. A region is a physical space in which a regional community meets its needs; it is a concept of region used by an inclusive and Marxist version of modernization theory. The first concepts mentioned above emphasized regional awareness superstructured on regional patterns of satisfying needs, while the latter objectively existing structure of regional economy and society. Recently an institutional perspective has been developed. Such a theoretical perspective makes us see a region in terms of relational qualities of regional space, institutions, society as well as symbols and myths created in the public discourse.
\end{abstract}

Key w ords: sociology of region; history of Polish sociology; region; regional identity; regional space
JACEK PONIEDZIALEK

Uniwersytet Warmińsko-Mazurski w Olsztynie. Correspondence: jacek.poniedzialek@wp.pl

This is an Open Access article distributed under the terms of the Creative Commons Attribution 3.0 PL License (creativecommons.org/licenses/by/3.0/pl/), which permits redistribution, commercial and non-commercial, provided that the article is properly cited. (C) The Author(s) 2015

Publisher: Institute of Slavic Studies PAS [Wydawca: Instytut Slawistyki PAN] 
Celem artykułu jest przedstawienie najważniejszych koncepcji regionu w polskiej socjologii. Po drugiej wojnie światowej większość socjologicznych studiów nad regionem wykorzystywała koncepcję regionu, w której definiowano go jako prywatną ojczyznę regionalnej społeczności, która integrowana jest przez regionalną tożsamość. Taka zbiorowość zamieszkuje terytorium traktowane jako fizyczny pojemnik tożsamości i kultury. Region to przestrzeń fizyczna, na której regionalna zbiorowość zaspokaja swoje potrzeby, to koncepcja regionu wykorzystywana przez integralną i marksistowską wersję teorii modernizacji. Pierwsze ze wspomnianych ujęć podkreślało ważność regionalnej świadomości nadbudowanej nad regionalnymi wzorami zaspakajania potrzeb, drugie obiektywnie istniejące struktury regionalnej gospodarki i zbiorowości. Ostatnio rozwija się perspektywa instytucjonalna, która każe widzieć region w kategoriach relacyjnych związków przestrzeni, instytucji, zbiorowości regionalnej oraz wytwarzanych w publicznym dyskursie symboli i mitów.

Słowa kluczowe: socjologia regionu; historia socjologii polskiej; region; tożsamość regionalna; przestrzeń regionu

W niniejszym artykule scharakteryzuje najważniejsze w moim mniemaniu koncepcje regionu, które wypracowane zostały po II wojnie światowej w polskiej socjologii. Celem tekstu jest wykazanie istniejącego silnego podporządkowania problematyki regionalnej studiom nad etnicznością i narodem, co znajduje wyraz w dominującej w socjologicznych badaniach regionu w Polsce pozycji humanistycznej koncepcji regionu-ojczyzny prywatnej, która swymi korzeniami sięga okresu międzywojennego. Dodatkowo chciałbym pokazać próby wyemancypowania się socjologii regionu jako samodzielnej subdyscypliny, jakie podjęto w podejściu zwanym perspektywą modernizacyjną oraz w koncepcji integralnej. Zakładam, że pomimo tego, iż badania problematyki regionalnej podejmowano już $w$ latach dwudziestych $X X$ wieku socjologia regionu nie potrafiła wyzwolić się spod wpływu socjologii narodu, będąc w pewnej mierze jej nauką pomocniczą. Zaś podjęte próby albo były wariacją koncepcji humanistycznej, albo przez radykalną zmianę teoretyczną i przedmiotową polegającą na zwróceniu się ku obiektywnie obserwowalnym wskaźnikom społecznym i ekonomicznym doprowadziły do zerwania związków socjologii regionu i socjologii narodu przy jednoczesnym zubożeniu teoretycznym tej pierwszej. Wykażę również, że w ostatnich latach pojawiła się perspektywa teoretyczna $w$ badaniach regionalnych nawiązująca do instytucjonalizmu i strukturalnego konstruktywizmu, która pozwala na wyzwolenie się badań regionalnych w socjologii spod dominującego wpływu humanistycznej koncepcji regionu. Mowa tu o ujęciu zwanym instytucjonalizacją regionu, gdzie wykorzystuje się elementy podejścia humanistycznego z niektórymi wątkami perspektywy modernizacyjnej oraz odwołuje się do teorii instytucjonalizacji. W pierwszej części analizie poddana jest koncepcja regionu-ojczyzny prywatnej, dalej scharakteryzowana jest perspektywa modernizacyjna oraz podejście integralne. W ostatnim fragmencie zaprezentowana będzie koncepcja zwana instytucjonalizacją regionu. Dodam, że prezentowany tu przegląd nie jest wyczerpujący, niemniej jednak wydaje się, że ów opis zawiera propozycje najistotniejsze z punktu widzenia ich doniostości heurystycznej i wartości empirycznej. 
Jedną z najważniejszych postaci dla socjologii regionu w Polsce po zakończeniu II wojny światowej jest niewątpliwie Stanisław Ossowski. Uczony formację intelektualną uzyskał w dwudziestoleciu międzywojennym, studiując u filozofów logików Jana Łukasiewicza, Władysława Tatarkiewicza i Tadeusza Kotarbińskiego; u tego ostatniego napisał pracę doktorską z zakresu semiotyki. Studiował również u Bronisława Malinowskiego. Interesował się także estetyką, co dzięki analizom sztuki i kultury nakierowało go na socjologię. Tuż przed wojną napisał książkę poświeconą problematyce socjologicznej, mianowicie Więź społeczna i dziedzictwo krwi (Ossowski, 1966). Zajął się w niej wpływem mitów i ideologii na rzeczywistość społeczną w kontekście narastającego wówczas w Europie rasizmu. W czasie trwania wojny napisał pracę poświęconą problematyce narodu, która we fragmentach została opublikowana już po jej zakończeniu (Ossowski, 1967). Najważniejsze dla socjologii regionu prace napisane zostały również po 1945 roku.

Uczony rozpoczyna badania w roku 1945 we wsi Dobrzeń Wielki na Śląsku Opolskim, początkowo wspomagany przez asystenta Jana Strzeleckiego. W roku 1947 przybywa do wsi ponownie wraz z asystentami Stefanem Nowakowskim, Zygmuntem Pióro, Maciejem Czerwińskim oraz grupą studentów. Pokłosiem śląskich badań była publikacja zatytułowana Zagadnienia więzi regionalnej i więzi narodowej na Śląsku opolskim (Ossowski, 1984). W latach 1948-49 Ossowski wraz ze współpracownikami, Jerzym Szackim, Wacławem Makarczykiem, Wandą Górszczyk i innymi, podjął badania we wsiach Rumy i Dźwierzuty na Mazurach, a także Leszno i Purda na Warmii. W wyniku likwidacji socjologii akademickiej w stalinowskiej Polsce i odsunięcia Ossowskiego na margines życia naukowego wyniki tych badań nie zostały opracowane i opublikowane. Część z nich po odnalezieniu została wydana w publikacjach naukowych poświęconych problematyce regionalnej na Warmii i Mazurach (Traba, Sakson, 2007; Poniedziałek, 2011). W oparciu o te badania, wcześniejsze studia nad narodem oraz przyjętą i rozbudowywaną socjologię humanistyczną Ossowski zaproponował i upowszechnił koncepcję regionu, która do dziś jest w badaniach regionalnych, w szczególności w socjologii, wykorzystywana najczęściej.

Uczony przyjmował, że zjawiska społeczne mają swój początek w świadomościowym wymiarze funkcjonowania człowieka uwikłanego w fenomen życia zbiorowego. Więzi społeczne, w tym regionalne i narodowe, to mający realne konsekwencje społeczne i kulturowe efekt przekonań i wyobrażeń. Powiada Ossowski, że więź społeczna to

... system postaw psychicznych, wspólnych poszczególnym członkom zbiorowości, a charakteryzujących ich stosunek do innych członków i do społeczeństwa jako całości. Składają się na nią aprobująca przynależność do grupy, tendencja do zachowania najważniejszych konformizmów grupowych, kult wspólnych wartości, świadomość wspólnych interesów (Ossowski, 1983, s. 47).

Dla Ossowskiego region w rozumieniu socjologicznym to korelat zbiorowości regionalnej, która ma poczucie odrębności „... ale nie uważa się za naród; inaczej mówiąc członkowie jej nie próbują przypisać swojej zbiorowości cech narodu" (Ossowski, 1967, s. 257). Taka zbiorowość zazwyczaj stanowi część większej zbiorowości narodowej. Tego typu zbiorowość funkcjonuje dzięki więzi społecznej o charakterze regionalnym. W świadomości jej członków rodzi się dzięki osobistym kontaktom poczucie wspólnoty z innymi jej członkami oraz poczucie odrębności od tych, którzy są pod różnymi względami inni. 
To poczucie identyfikacji i odrębności generowane przez uświadamiane sobie wyróżniki (realnie istniejące, np. język, czy specyficzne obyczaje lub wyobrażone, np. stereotypy i mity) buduje świadomość regionalną. Ta zaś tworzy się i przybiera na sile wówczas gdy dochodzi do kontaktu z Innym. W odniesieniu do tego aspektu rozważań nad regionem można stwierdzić, że Ossowski kontynuuje koncepcje ksztattowania się regionu przez powstawanie tożsamości regionalnej (nazywanej świadomością regionalną) zapoczątkowane w okresie dwudziestolecia międzywojennego przez Józefa Obrębskiego w badaniach nad kulturą ludową Poleszuków i Józefa Chałasińskiego badającego Górnoślązaków we wsi Murcki pod Katowicami (Obrębski, 1936; Chałasiński, 1935).

Więź regionalna, rozpowszechniona wśród regionalnej zbiorowości mającej poczucie swoistej odrębności, dotyczy ludzi ulokowanych w konkretnym, ograniczonym przestrzennie terytorium. Zbiorowość która je zamieszkuje uznaje je za własne, wraz z jej materialnymi wyróżnikami, prawdziwą lub zmityzowaną historią, która się do niego odnosi. Pozytywnie waloryzuje to ograniczone terytorium wraz z zamieszkującą je zbiorowością (Kubiak, 2007, s. 84). Ten osobisty stosunek jednostki do ziemi najbliższej nazywany jest przez Ossowskiego ojczyzną prywatną. Tego rodzaju więzi społeczne, terytoria i zbiorowości stanowią stały element dziejów i chronologicznie oraz logicznie wyprzedzają narody. Te zaś to duże grupy społeczne, które powstały w wyniku wykształcenia się wspólnej dla nich kultury, zamieszkują znaczne terytoria, cechują się występowaniem świadomości narodowej, która współkształtowana jest przez narodową ideologię. Korelatem narodu jest to, co Ossowski nazywa ojczyzną ideologiczna, która funkcjonuje nie w wyniku osobistych przeżyć, ale żywionych przez jednostkę przekonań o uczestnictwie w większej zbiorowości, jaką jest naród.

Naród w przeciwieństwie do regionu jest zbiorowością złożoną, obejmującą różne typy zbiorowości regionalnych i wszystkie odmiany struktur społecznych. Jest zasadniczo otwarty i w przeciwieństwie do regionu nastawiony aktywistycznie i ekspansjonistycznie wobec innych narodów czy zbiorowości regionalnych wchodzących w jego skład. Jest charakterystyczny dla modernizujących się społeczeństw świata nowoczesnego, uprzemysłowionego i umasowionego. Narody są w pewnym sensie zjednoczonymi w wymiarze wspólnej kultury i ideologii mniejszymi zbiorowościami lokalnymi i regionalnymi.

Przed wykształceniem się narodów nowoczesnych ojczyzny prywatne pokrywały się z ojczyznami ideologicznymi. Ossowski pisze, że w wyniku kształtowania się masowych narodów, co wiąże się z rozrastaniem się zbiorowości terytorialnych, ojczyzna prywatna przestaje pokrywać się z ideologiczną wchodząc w jej skład. Ojczyzny prywatne członków narodu mnożą się i zaczynają różnić. W nowoczesnym narodzie regiony są na tyle odrębne, że zarówno obszar ojczyzny prywatnej oraz jej specyfika kulturowa i świadomościowa różni się, biorąc pod uwage poszczególne regiony (Ossowski, 1984). Regiony stanowią punkt wyjścia kształtowania się narodów, następnie są jego składowymi, różniąc się od siebie, mają wiele cech wspólnych z narodem. W podobny sposób o kształtowaniu się narodu z ludu oraz konsekwencjach tego procesu dla grup ludowych (regionalnych) pisał znacznie wcześniej Florian Znaniecki (1990).

Dzięki swoim badaniom Ossowski dostrzegł skomplikowaną i nieoczywistą relację pomiędzy więziami regionalnymi i więziami narodowymi, a co za tym idzie tożsamością regionalną a tożsamością narodową. Więzi i tożsamości regionalne mogą być elementem składowym więzi i tożsamości narodowych, relacje pomiędzy nimi są niekonfliktowe, poziom regionalny podporządkowany jest poziomowi narodowemu (np. Wielkopolanie czy Górale Podhalańscy, dla których identyfikacja narodowa jest ważniejsza niż regionalna 
stanowiąca wzmocnienie i uzupełnienie pierwszej). Więzi i tożsamości regionalne stanowią równie ważny i dopełniający element więzi i identyfikacji z narodem (np. Kaszuba jest Polakiem, ale jego kaszubskość jest równie ważna jak polskość). Więzi i tożsamości regionalne mogą być waloryzowane wyżej niż więzi i tożsamości narodowe (np. najpierw się jest Ślązakiem, potem dopiero Polakiem lub Niemcem, lub najpierw się jest Warmiakiem czy Mazurem, następnie zaś Niemcem lub Polakiem).

Kolejne novum badań uczonego to konstatacja mówiąca o tym, że w relacjach pomiędzy więzią regionalną i narodową na pograniczach narodów i kultur (za takie uważał Śląsk, Mazury i Warmię), często dochodzi do dominacji więzi regionalnej nad narodową, która stanowi podstawową formę funkcjonowania w regionalnej społeczności. Na przykładzie Śląska Opolskiego skonstatowat, że wówczas region jako ojczyzna prywatna zaczyna pełnić funkcję ojczyzny ideologicznej. Zaskoczyło to samego Ossowskiego, który wcześniej kategorycznie twierdził, że ojczyzną ideologiczną może być tylko naród. Zauważył również, że w przypadku gdy więź i tożsamość regionalna są równe lub wyżej stawiane niż więzi i tożsamości narodowe, częściej występuje w regionach zjawisko indyferentyzmu i zmienności narodowej. Relacje pomiędzy różnymi grupami, Ślązakami, Niemcami a ludnością napływową wyznaczane były przez

... korelaty świadomościowe takie jak język, pochodzenie regionalne, odmienne losy historyczne i indywidualne doświadczenia określające pamięć przeszłości grupowej ukazało, [to przyp. J. P.] działanie socjologicznego „prawa tła” czyniącego Niemców bliższych Ślązakom niż Polakom, których nie rozumieli i których nazywali Ukraińcami (Sołdra-Gwiżdż, 2014, s. 105).

Poza czynnikami etnicznymi i kulturowymi na kształtowanie się skomplikowanych relacji regionu z narodem wpływ mają również czynniki klasowe i ekonomiczne. Więzi i tożsamości regionalne Ślązaków w badanej społeczności wykazywały się intensywnym związkiem z polskością wówczas gdy dotyczyły samodzielnych, relatywnie dobrze sytuowanych rolników, w mniejszym zaś stopniu dotyczyło to robotników, wśród których silniejsze były więzi regionalne czy powszechniejszy był indyferentyzm narodowy.

Ossowski nie stworzył odrębnej teorii regionu. Problematyka regionalna interesowała go jako element większej całości, mianowicie socjologii narodu. W tym wymiarze jego twórczość była kontynuacją rozważań nad narodem, która tak intensywnie podejmowana była w okresie międzywojennym. Analiza relacji ojczyzny prywatnej-regionu i ojczyzny ideologicznej-narodu, więzi regionalnych i więzi narodowych, tożsamości regionalnych i narodowych zawsze u Ossowskiego miała za punkt odniesienia studia nad narodem. Tym samym socjologia regionu pełniła funkcję swoistej służebnicy socjologii narodu, co każe umieszczać jego twórczość w „... ramach polskiej szkoły narodowej” (Pucek, 1992, s. 29). Współcześnie często zarzuca się tej koncepcji, że de facto zawęża region do subiektywnie odczuwanego istnienia „... zbiorowości regionalnej, a jeszcze bardziej społeczeństwa regionalnego, albo grupy terytorialnej" (Rykiel, 2008, s. 22). Na margines zainteresowań zepchnięta została problematyka wpływu przestrzeni fizycznej i jej właściwości na kształtowanie się regionu, typów aktywności społecznej i ekonomicznych, czy szerzej społecznych i gospodarczych wzorców funkcjonujących w jego obrębie. Nie zastanawiał się również Ossowski nad wpływem instytucji politycznych na kształtowanie więzi regionalnych i ich relacji z narodem. Można również wykazać, że wiele pomysłów badacza uznanych za zupełnie nowe były już, przynajmniej częściowo, sygnalizowane wcześniej. Dotyczyć to może kształtowania się narodu i jego relacji z regionami, idee zaczerpnięte po części z twórczości Floriana Znanieckiego, świadomościowego wymiaru funkcjonowania 
regionu, co wykazał już Józef Obrębski, czy dominacji poczucia odrębności regionalnej nad narodową, co z kolei udowodnił wcześniej Józef Chałasiński. Pomimo powyższych uwag wkład Ossowskiego do socjologicznych badań nad regionami, tożsamościami regionalnymi i ich relacjami z narodami jest niewątpliwy. Uczulił następne pokolenia badaczy na konieczność zwracania uwagi na subiektywne wyróżniki regionu, skomplikowane i zmienne relacje różnych typów i poziomów tożsamości oraz wykazał możliwość ich zmiany. O wadze i sile zaproponowanej przez uczonego koncepcji świadczy to, iż na lata dla wielu pokoleń badaczy problematyki regionalnej była ona teoretyczną podstawą badań empirycznych.

Likwidacja socjologii uniwersyteckiej i wypchnięcie poza socjologię akademicką Ossowskiego sprawiły, że badania nad regionami w Polsce wyhamowały. Na nowo podjęte zostały wraz z zakończeniem stalinizmu w Polsce. Recepcja i zastosowanie w badaniach empirycznych humanistycznej koncepcji regionu jako ojczyzny prywatnej związane było z problematyką adaptacji i integracji społeczno-kulturowej ludności, która w wyniku powojennych ustaleń i związanych z nimi przesunięć terytorialnych i przemieszczeń ludności zamieszkała nowe regiony nazwane ziemiami odzyskanymi. Współcześnie noszą ona nazwę Ziem Zachodnich i Północnych. Badania regionalne realizowano wówczas w naukowej perspektywie paradygmatu integracyjnego, gdzie sięgając do koncepcji Ossowskiego udowadniano, że dokonała się adaptacja społeczna nowych mieszkańców do ziem, na których przyszło im zamieszkać. Wskazywano również na wewnętrzną integrację społeczno-kulturową, dzięki której wykształciły się nowe zbiorowości regionalne. Powstały nowe regiony-ojczyzny prywatne, będące częścią narodu-ojczyzny ideologicznej, powstałe więzi i tożsamości regionalne stanowiły wariację więzi i tożsamości narodowych będąc wobec nich podrzedne (Poniedziałek, 2011, ss. 103-110).

Zauważa Aleksander Posern-Zieliński, że byłoby znacznym

... uproszczeniem twierdzić, iż do takich tylko wyników sprowadzały się realizowane wówczas studia. Ukazywały one w miarę możliwości sporo rzeczywistych i dramatycznych w swym charakterze procesów i konfliktów, ale zjawiska te były spychane na dalszy plan, gdyż musiały ustąpić przed pozytywną wizją integracyjną (Posern-Zieliński, 1995, s. 304).

Prace dotyczące Kaszubów, Mazurów czy Warmiaków mogące nadmiernie eksponować wymiar regionalny kosztem narodowego spotykały się ze zinstytucjonalizowaną niechęcią. Był to bowiem okres, kiedy władze polityczne „... szczególnie akcentowały jedność moralno-polityczną narodu" (Malikowski, 1998, ss. 102-103). W prowadzone badaniach regionalnych wykorzystujących zredukowaną koncepcję Ossowskiego, w dużej mierze dominowała teza o jedności etnicznej, narodowej i kulturowej Polski (Ciechocińska, 1983, s. 73).

Po przełomie roku 1989 koncepcja wypracowana przez Ossowskiego nie została odłożona do naukowego lamusa. Badacze problematyki regionalnej, odrzucając paradygmat integracyjny, na powrót zaczęli korzystać z całego bogactwa humanistycznej koncepcji regionu-ojczyzny prywatnej. W badaniach socjologicznych region ujmowano jako zbiorowość spajaną wspólną kulturą i tożsamością regionalną, zamieszkującą dostatecznie długo jakąś przestrzeń. Jej relacje z narodem są złożone, od bycia integralną jego częścią przez regionalny indyferentyzm a nawet jego zastępowanie przez region, w którym zachodzą procesy o charakterze narodotwórczym. Do badaczy problematyki regionalnej, odwołujących się do koncepcji Ossowskiego bądź powielających jego pomysły nawet wówczas gdy wprost się do jego twórczości nie odnoszą, zaliczyć można Andrzeja Saksona badającego przemiany dokonujące się wśród Mazurów, Cezarego Olbracht-Prondzyńskiego ba- 
dającego społeczności Kaszubów, czy Elżbietę Sekułę zajmująca się badaniem przemian tożsamości regionalnej i narodowej Górnoślązaków (Sakson, 2006; Obracht-Prondzyński, 2002; Sekuła, 2009). Podobnie problematykę opisuje wielu innych badaczy, traktując problematykę regionów jako uzupełnienie socjologii etniczności i narodu.

W tej odświeżonej humanistycznej optyce wskazuje się głównie na zbiorowość regionalną wraz z wyróżniającą ją kulturą i systemem społecznym kształtowanymi w długich procesach historycznych. Wskazane czynniki mogą stanowić budulec regionu tylko wtedy gdy implikują działania ludzkie pod wpływem określonego stanu świadomości, tylko wówczas gdy ludzie uświadamiają sobie istnienie regionu wraz z jego wyróżnikami i uznają je za istotne. Stąd przyjmuje się tu, że jednym z najistotniejszych kryteriów istnienia regionu jest tożsamość regionalna rozpowszechniona w świadomości jego mieszkańców. Oczywistym jest, że istnienie zbiorowości regionalnej połączonej więziami społecznymi i tożsamością jest warunkiem sine qua non istnienia regionu. Region to regionalna grupa społeczna ze specyficznymi dla siebie strukturami społecznymi i specyficznie skonfigurowanymi elementami wyróżniającej je kultury. Gospodarka i przestrzeń fizyczna regionu wraz z jej korelatami mają drugorzędne znaczenie, albowiem stanowią zaledwie tło dla funkcjonowania prymarnej wobec niej zbiorowości regionalnej spajanej wspólną tożsamością (Chojnicki, 1993, s. 13). Brak w tym ujęciu uznania ważności relacji pomiędzy wskazywanymi elementami tworzącymi region. Charakteryzuje się jakości wymieniane jako składowe regionu, milcząco zakładając, że istnieją pomiędzy nimi złożone relacje, choć nie wiadomo, jaki one mają charakter.

Próbą uzupełnienia koncepcji humanistycznej jest ujęcie zaproponowane przez Waltera Żelaznego. Badacz zgadzając się z humanistycznym konceptem regionu ojczyzny prywatnej, odwołując się do twórczości Jeana Labasee, proponuje wprowadzenie nowej dwuelementowej typologii regionów. Pierwszy nazywa formalnym, stwierdza że jest to pewna forma organizacji terenowego ustroju państwa. Takie regiony posiadają pewien stopień podmiotowości decyzyjnej, nie implikują jednak wewnątrzregionalnej aktywności politycznej, brak w nich również wyraźnych swoistości kulturowych mogących stanowić podstawę formowania się mechanizmów integrowania i upodmiotawiania regionalnych zbiorowości. Empirycznymi przykładami takich regionów mogą być angielskie hrabstwa, francuskie departamenty czy polskie województwa. Drugi z wyabstrahowanych typów, noszący nazwę integralnego, jest konkretną przestrzenią wraz z zamieszkującą go zbiorowością, którą cechuje specyficzna tożsamość oraz wyraźnie występujące aspiracje polityczne do regionalnego samostanowienia. Są one pochodną odmienności etnicznych i politycznych zbiorowości zamieszkujących region (Walia, Katalonia, Bretania), czy historyczno-etnicznych (Bawaria, Śląsk, Szkocja). Wskazanym wyżej odmiennościom ukształtowanym na bazie przeszłości towarzyszyć mogą specyficzne trajektorie rozwoju gospodarczego regionów rzutujące na formowanie się ich specyfiki (Żelazny, 1998, s. 36). Chodzi o taki typ przestrzennego zjawiska społecznego, które konstytuowane jest przez czynniki: społeczno-kulturowe (etniczna lub kulturowa odmienność), polityczne i historyczne (odrębne dzieje i istniejący obecnie lub w przeszłości jakiś stopień politycznego samostanowienia) czy powiązane z nimi odmienności w rozwoju gospodarczym. Ta klasyfikacja de facto powiela znany $w$ literaturze podział na regiony administracyjne, etniczne, społeczne, gospodarcze czy reliktowe. Autor odwołuje się przy tym do przywoływanej wcześniej perspektywy humanistycznej, wylicza cechy zbiorowości regionalnej (kultura, tożsamość, odmienne dzieje itp.), skupiając się na jej statycznych cechach. Rozważanie problematyki regionalnej również w tym przypadku pozostaje w cieniu studiów nad narodem i etnicznością. 
Druga warta uwagi próba udoskonalenia humanistycznej koncepcji regionu podjęta została przez Jerzego Bartkowskiego. Warszawski socjolog zaproponował własną typologię regionów. W pierwszej grupie wyszczególnionych przez niego znajdują się regiony wyznaczane w oparciu o funkcjonujące w rzeczywistości kryteria geograficzne, kulturowe czy historyczne. Przyjmuje się tu, że regiony są uznane i empiryczne badaczowi dane, ich granice i cechy dystynktywne wyznaczane są przez nature i historię. W drugiej grupie znajdują się te tworzone w oparciu o sztuczne podziały racjonalne i techniczne, w tym ujęciu regiony są również empirycznie uchwytne, jednakże ich granice i niektóre cechy mają charakter sztuczny. Tworzone są z reguły na potrzeby administracyjnego zarządzania jakimiś obszarami danego państwa. Trzecią grupę stanowią te, które tworzone są w oparciu o kryteria analityczne, tu regiony z ich specyfikami tworzą sami badacze dla celów poznawczych (Bartkowski, 2003, s. 23). Powyższa próba uporządkowania kryteriów definiowania regionów to zapożyczenie propozycji podziału regionów na przedmiot poznania, narzędzie badawcze i region jako narzędzie działania wprowadzone do polskiej nauki przez geografa Kazimierza Dziewońskiego (Dziewoński, 1967).

Bartkowski w swojej książce zatytułowanej Tradycja i polityka. Wpływ tradycji kulturowych polskich regionów na współczesne zachowania polityczne i społeczne bada zróżnicowane regionalnie wzory zaangażowania społecznego i obywatelskiego, a także politycznego. Zauważa, że poszczególne regiony, różniąc się między sobą, wykazują liczne podobieństwa i wówczas wpisują się w podział będący rezultatem dziedzictwa zaborów. I tak pomimo różnic Górny Śląsk, Wielkopolska i Kaszuby, były zabór pruski, wykazują wiele podobieństw. Odróżniają się znacznie od regionów wchodzących w skład byłej tzw. Kongresówki, czyli zaboru rosyjskiego (np. Mazowsze czy Lubelszczyzna) czy Galicji (np. Małopolska, świętokrzyskie) znajdującej się przed rokiem 1918 pod panowaniem Austro-Węgier. Kolejny podział regionalny generowany jest przez różnice będące pochodną zmian terytorialnych, jakich doświadczyła Polska po zakończeniu II wojny światowej. Autor wykazał, że regiony Ziem Zachodnich i Północnych (np. Dolny Śląsk czy Warmia i Mazury) cechuje wysoki stopień podobieństw przy licznych odmiennościach w odniesieniu do regionów będących częścią II Rzeczypospolitej. Badacz stwierdza, że region cechuje odrębność społeczno-kulturowa charakterystyczna dla jakiejś przestrzeni, a także „... występujące elementy więzi społecznej i świadomości regionalnej” (Bartkowski, 2003, s. 24). Stwierdza, że badając region, uczeni, w szczególności socjologowie, powinni spróbować odpowiedzieć na pytanie

... kiedy przestrzenne współwystępowanie odrębności społecznych staje się regionem. Cechy wyróżniające region powinny tworzyć wyrazisty, indywidualny zespół, który jest czymś więcej niż tylko przejawem odmienności struktur ekonomicznych i demograficznych, bądź nierówności rozwoju społeczno-ekonomicznego. Cechy regionu winny składać się na samoistną, funkcjonalną całość, w której można wyróżnić dominantę, będącą jednoczesną syntezą odrębności regionalnej i zarazem najbardziej charakterystycznym dla niej wyznacznikiem (Bartkowski, 2003, s. 24).

To ciekawe i zasługujące na uwage ujęcie, będące próbą połączenia koncepcji geograficznych i socjologicznych. Podobnie jak w ujęciu humanistycznym Bartkowski uwypukla ważność specyficznie strukturalizowanej kultury i tożsamości regionalnej, będącej pochodną wewnętrznego podobieństwa, zewnętrznej odrębności i konstytuujących obie te cechy granic społecznych i przestrzennych (Bartkowski, 2005). Warszawski badacz poprzez uwypuklenie konieczności wypracowania wewnątrz regionu funkcjonalnej równowagi pomiędzy strukturalnymi i świadomościowymi wymiarami istnienia regionu po- 
wiela w znacznej mierze stanowisko Józefa Obrębskiego, któremu blisko było do antropologicznego funkcjonalizmu. Również w tym wypadku brak systematycznej i pogłębionej analizy interakcji i wewnętrznych powiązań elementów tworzących region. Jak zauważa Zbigniew Rykiel, takie ujęcie każe widzieć region jako jednostkę „... opartą na podobieństwie struktury wewnątrz regionu i odrębnościach strukturalnych od innych regionów, nie zaś na powiązaniach. [....] Oznaczałoby to, że konstytutywne dla regionu są statyczne struktury społeczne, nie zaś dynamiczne interakcje" (Rykiel, 2011, s. 68). Pomimo wymienionych słabości wskazana koncepcja stanowi uzupełnienie ujęć humanistycznych o elementy wypracowane w społeczno-ekonomicznej geografii regionu, co umożliwia pełniejszą klasyfikację regionów. Pomimo silnych związków z koncepcją regionu-ojczyzny prywatnej stanowi krok w kierunku pełnej emancypacji socjologii regionu.

\section{REGION W PERSPEKTYWIE MODERNIZACYJNEJ}

Na przełomie lat sześćdziesiątych i siedemdziesiątych XX wieku do opisu problematyki regionalnej zaczęto używać kategorii pojęciowych wyrastających z paradygmatu modernizacji. Wpływ na zwiększone zainteresowanie socjologów regionem miało powstanie regional science, ekonomicznej refleksji dotyczącej problematyki rozwoju społeczno-ekonomicznego regionów. Powstanie tego typu badań regionalnych związane jest z nazwiskiem amerykańskiego ekonomisty Waltera Isarda, badającego wpływ przestrzennie zlokalizowanych czynników rozwoju na przebieg procesów gospodarczych (Miazga, 2010, s. 15). W tej perspektywie teoretycznej zakłada się funkcjonalność wszystkich segmentów systemu społeczno-gospodarczego i konieczność wypracowania naukowych podstaw programów stymulowania wzrostu zamożności w społeczeństwie jako całości oraz w poszczególnych regionach będących elementami sytemu państwowego. W takim rozumieniu, jak podkreśla Philip McMichael, regiony stanowią element systemu państwowego i międzynarodowego zorganizowanego wokół takiego celu, jakim jest bogactwo uzyskiwane głównie dzięki postępowi technicznemu i handlowi (McMichael, 1998, s. 286). Te mające swoje źródła w przeddziewiętnastowiecznym merkantylizmie, ekonomicznym liberalizmie i społecznym ewolucjonizmie założenia, każą traktować region jako wewnętrznie zbalansowany system społeczno-gospodarczy będący częścią większego systemu państw, a następnie systemu porządku międzynarodowego (Starosta, 1999, s. 41).

Utrzymywano, że świat, poszczególne państwa oraz regiony, będą rozwijać się zgodnie z uniwersalnym wzorcem, biorąc za przykład najlepiej rozwinięte regiony i państwa świata. Na takich fundamentach ontologicznych zaczęto instytucjonalizować socjologię regionu jako wydzieloną subdyscyplinę. Nastąpiło to w roku 1970 na Kongresie Międzynarodowego Stowarzyszenia Socjologicznego w Warnie, gdzie powołano do życia Komitet do Badań Rozwoju Regionalnego i Miejskiego (Research Committee on Sociology of Urban and Regional Development), socjologia regionu miała stać się subdyscypliną praktyczną, rodzajem inżynierii społecznej usprawniającej procesy planowania przestrzennego i gospodarczego. Na obszarze socjologii regionu mającej za podstawę ustalenia ekonomicznej teorii wzrostu wypracowano szereg zaleceń dotyczących społeczno-ekonomicznego rozwoju regionów (Ciechocińska, 1976, s. 202). Przyjmowane wówczas ustalenia dotyczące regionów 
... zrodzity praktyczne potrzeby realizacji teorii wzrostu w praktyce w odniesieniu do wybranych regionów. Wzrost zapotrzebowania na ustalenia socjologii regionalnej był widoczny np. przy obserwacji ewolucji, jaka się dokonała z biegiem lat w programach wyspecjalizowanych agend ONZ zajmujących się rozwojem społeczno-gospodarczym (Ciechocińska, 1983, s. 68).

Wzrost popularności paradygmatu modernizacyjnego w światowej socjologii wpłynął również na socjologię polską. W latach siedemdziesiątych i osiemdziesiątych XX wieku w studiach nad regionem zaczęła dominować nowa perspektywa teoretyczna, która zyskała miano modernizacyjnej. Warto jednak zauważyć, że w odniesieniu do Polski była to swego rodzaju marksistowska wersja teorii modernizacji, gdzie wzorcem i punktem docelowym rozwoju społeczno-gospodarczego regionów miał być model państwa socjalistycznego (Gorlach, 2004, s. 128). Wzrost popularności tej perspektywy wiązał się z zepchnięciem na margines humanistycznych koncepcji regionu wypracowanych przed II wojną światową i rozwiniętych przez Stanisława Ossowskiego już po jej zakończeniu. Utrzymywano, że polskie studia nad regionem zdominowała problematyka etnologiczna i subiektywistyczny charakter opisu regionu. Polscy badacze regionów odwołujący się do perspektywy modernizacyjnej widzieli konieczność nowego zdefiniowania regionu i co za tym idzie zakreślenia obszaru dociekań socjologii regionu. Maria Ciechocińska wskazuje, że istniał wówczas deficyt prawdziwie socjologicznych ujęć problematyki regionalnej, zaś obiektywne wskaźniki społeczno-ekonomiczne zdominowane przez subiektywne wymiary istnienia regionu nie były brane pod uwage (Ciechocińska, 1983, ss. 73-74). Do wskaźników mających zrewolucjonizować socjologię regionu nie zaliczono poczucia tożsamości oraz kulturowych wyróżników regionu w ich wymiarze symbolicznym a także materialnym.

Badacze piszący o regionie w perspektywie modernizacyjnej przyjęli założenie, że region jest bytem realnie istniejącym. Punktem wyjścia jest stwierdzenie, że jest to przestrzeń funkcjonalna, gdzie zaspakajane są potrzeby jej mieszkańców. To obszar o hierarchicznej strukturze jednostek osadniczych wraz z ośrodkami infrastruktury społecznej, które umożliwiają zaspakajanie potrzeb. Punktem centralnym tego hierarchicznego układu jest stolica regionu, której oddziaływanie zamknięte jest w jego granicach najczęściej definiowanych w kategoriach podziału administracyjnego. Struktura regionu jest spójnym i logicznym układem społeczno-przestrzennych elementów. Ze strukturalnego zróżnicowania przestrzeni regionu wynika różna dostępność do możliwości zaspakajania potrzeb. Decydują o tym czynniki obiektywne (rozkład jednostek osadniczych, rozmieszczenie zakładów pracy itp.) generujące zróżnicowanie społeczne, różny w zależności od zajmowanego miejsca $\mathrm{w}$ regionalnym układzie przestrzennym prestiż społeczny, pozycja społeczna oraz materialny status mieszkańców regionu. Tak rozumiany region ma swoje początki w przeszłości. W praktyce na przestrzeni czasu ukształtowała się jego specyfika produkcyjna, struktury społeczne, potrzeby i regionalne wzory ich zaspakajania. Wszystko to zaś rodzi pewien typ świadomości będący pochodną obiektywnie istniejących stosunków produkcji, społecznych struktur i sieci osadniczej. Mówiąc po marksistowsku, regionalny byt określa regionalną świadomość (Ciechocińska, 1978).

Region jako hierarchiczny i funkcjonalny układ społeczno-przestrzenny stał się obiektem badań zróżnicowań społecznych i gospodarczych wynikających z trzech grup czynników: „... 1) wpływu centralnie planowanego i realizowanego uprzemysłowienia na poszczególne obszary kraju, 2) społecznych skutków nierównomiernego rozwoju gospodarczego, 3) regionalnych barier szans życiowych ludzi" (Malikowski, 1998, s. 102). Badania regionalne, które konstruowano i realizowano z użyciem opisanej tu opcji teoretycznej, koncentrowały się na procesach modernizacji regionów i konieczności sterowania tymi 
procesami. W efekcie przyniosto to rozumienie regionu jako struktury społeczno-produkcyjno-konsumpcyjnej ulokowanej w konkretnej przestrzeni fizycznej (Ciechocińska, 1978, s. 198). Badania regionu miały gtównie diagnostyczno-opisowy charakter, skupiano się w nich na przestrzennym zróżnicowaniu dochodów i konsumpcji czy nierówności w dostępie do infrastruktury społecznej.

Efekty badań regionów w tej perspektywie znalazły się w serii publikacji wydawanych pod patronatem Komitetu Badań Regionów Uprzemysławianych PAN, z syntezą tych badań zawartą w publikacji pt. Zmiany społeczeństwa polskiego pod wpływem uprzemysłowienia autorstwa Jana Szczepańskiego na czele (Szczepański, 1973). Po roku 1980 socjologiczne badania regionów objęły głównie jednostki administracyjne, jakim były wprowadzone województwa. Ich funkcjonowanie stało się głównym przedmiotem badań regionalnych. Wyniki tych badań opublikowano w kilkudziesięciotomowej serii publikacji noszącej tytuł Rozwój lokalny - rozwój regionalny - samorząd terytorialny, która miała stać się źródłem wiedzy i zaleceń praktycznych dla władz centralnych i wojewódzkich. Lata siedemdziesiąte i osiemdziesiąte pomimo zintensyfikowanych badań nad regionami przyniosły niewiele jeżeli chodzi o rozwój socjologicznej teorii regionów. W większości publikacji z tego okresu region definiowano arbitralnie, najczęściej jako wyodrębniający się od innych na podstawie jakiejś cechy obszar, a częściej jako przestrzennie wyodrębniony na użytek konkretnych badań teren konstytuowany przez możliwość statystycznego zbierania danych mogących go charakteryzować (Ciechocińska, 1976, s. 202). Jak wspominałem, badano rozwój infrastruktury gospodarczej i społecznej w województwach, dostęp do niej, analizowano również rozwój miast wojewódzkich. Nie badano jednak subiektywnej oceny tych zjawisk przez mieszkańców, nie analizowano faktycznych nierówności, których zgodnie z socjalistyczną doktryną być nie powinno.

Na uwagę zasługują rozważania Janusza Ziółkowskiego poświęcone problematyce regionu, które wpisują się w perspektywę modernizacyjną. Na pierwszy rzut oka zaproponowana przez tego badacza koncepcja nie wnosi wiele nowego do problematyki regionalnej, autor definiuje bowiem region jako obszar „... charakteryzujący się pewną cechą czy zespołem cech wspólnych, które wyodrębniają go od innych obszarów" (Ziółkowski, 1972, s. 7). Jednorodność tego obszaru może być pochodną jego właściwości przyrodniczych, ekonomicznych lub społecznych i kulturowych. Długie zamieszkiwanie wspólnego, wyróżniającego się obszaru buduje spajające zbiorowość więzi i poczucie odrębności. Co niezwykle istotne, region konstytuuje swoista dla niego konfiguracja zjawisk gospodarczych dopełniających jego specyfikę. Novum w ówczesnej polskiej socjologii regionu było nawiązanie przez Ziółkowskiego do teorii centrum-peryferii, jednej z odmian teorii modernizacji. Poznański socjolog charakteryzuje podział regionalny przez tworzący go binarny układ regionów dobrze społecznie i gospodarczo rozwiniętych (centrum), oraz eksploatowanych przez nie regionów słabych i zacofanych (peryferia). Wykształca się w ten sposób trwały podział regionalny, który w dłużej perspektywie jest niebezpieczny dla rozwoju kraju jako całości, przez co wymaga korekt. Zarówno w tej koncepcji, jak i pozostałych wypracowanych na obszarze perspektywy modernizacyjnej socjologowie odeszli od koncepcji etnograficznych oraz wypracowanych na obszarze socjologii humanistycznej kulturowych i subiektywistycznych definicji regionu, zastępując je definicjami obiektywistycznymi, eksponując strukturalne i gospodarce przejawy jego funkcjonowania.

Początkowy entuzjazm towarzyszący paradygmatowi modernizacji dotyczący możliwości szybkiego, odwzorowanego na uniwersalnej trajektorii rozwojowej wzrostu globalnej gospodarki (a co za tym idzie również gospodarek narodowych i regionalnych) oraz 
podążających za nimi zmian w strukturze społecznej, uległ z czasem znacznemu zredukowaniu. Jak powiada Iwona Sagan, zauważono, że wzrost gospodarczy i transformacja struktury społecznej napotykają liczne trudności, mają różne źródła oraz często odmienny przebieg w zależności od konkretnego kontekstu społecznego, politycznego i gospodarczo-kulturowego (Sagan, 2011, ss. 35-49). Niemożliwe również okazało się utworzenie scjentystycznej socjologii regionu, z obszaru zainteresowań której usunięto by problemy badawcze dotykające czynników subiektywnych takich jak tożsamość, identyfikacja z regionalną kulturą czy poczucie odrębności. Okazało się, że regionu nie da się zredukować do wymiarów procesów gospodarczych mających w nim miejsce, które to da się racjonalnie zaplanować, mając za podstawę ustalenia płynące z socjologicznych badań. Przyjęty wówczas kierunek rozwoju subdyscypliny, który na polskim gruncie przyniósł skutek w postaci rozejścia się dróg socjologii regionu i narodu tak mocno splecionych w socjologii humanistycznej, okazał się ślepą uliczką. Zupełne odejście od wypracowanych w koncepcji humanistycznej ustaleń zubożyło teoretycznie socjologiczne badania nad regionem. Ta wersja socjologii regionu szybko okazała się niedorozwiniętą gałęzią planowania przestrzennego. Wart jednakże jest odnotowania fakt, iż region stał się $\mathrm{w}$ tej perspektywie przestrzenią relacyjną, gdzie mające miejsce procesy gospodarcze i społeczne formują zbiorowości regionalne $w$ takim samym stopniu co regionalna kultura i tożsamość. Co istotne, była to próba autonomicznego potraktowania regionu bez konieczności odwoływania się do socjologii narodu.

\section{KONCEPCJA REGIONU INTEGRALNEGO}

„Powojenny stalinizm inaczej potraktował socjologię i etnografię - podczas gdy ta pierwsza przestała de facto istnieć, druga zachowała wszystkie najważniejsze instytucje i czasopisma" (Łuczeczko, 2011, s. 63). W związku z tym etnografowie zachowali możliwości badań nad regionami zapoczątkowane w okresie dwudziestolecia międzywojennego. Od etnografii, którą potraktowano jako naukę historyczną, przede wszystkim oczekiwano badań, dokumentacji i upowszechniania wiedzy o kulturze ludowej. Badanie tej problematyki nie odbiegały od zasadniczego przedmiotu badań etnografii, jednym z jej zadań było badanie i

... dowartościowanie warstw, nieuczestniczących dotąd w pełni życia narodu; teraz jednak próbowano ją wykorzystać dla celów nowego ustroju. Posłużyła jednocześnie etnografom do schronienia się w miarę bezpiecznej niszy przed narzuceniem ideologii marksizmu-leninizmu (Jasiewicz, 2006, s. 68).

Zubożyło to znacznie ówczesną etnografię regionów teoretycznie. W znacznej części etnograficznych badań regionów okresu powojennego trudno odnaleźć nowatorskie idee i pomysły Józefa Obrębskiego, dotyczące chociażby fundamentalnej roli tożsamości budowanej przez kontakt z Innym. W badaniach przeważały deskryptywne charakterystyki poszczególnych regionów bądź poszczególnych działów kultury ludowej w regionach (Posern-Zieliński, 1995, s. 303). Rozeszły się drogi humanistycznej socjologii i etnografii regionu, pierwsza zignorowała materialne przejawy istnienia regionów, druga zaś zlekceważyła tożsamość jako czynnik regionotwórczy. W odniesieniu do etnografii można zauważyć, że „... swoisty gorset nauki historycznej, skupiającej się na kulturze materialnej będzie krępowat ją nadspodziewanie długo" (Łuczeczko, 2011, s. 63). Wyjątkiem będą 
nieliczni badacze problematyki regionów idący drogą wytyczoną przed II wojną przez Kazimierza Moszyńskiego oraz w większym stopniu Obrębskiego. Za przykład mogą tu służyć realizujący badania na Łemkowszczyźnie, w Beskidzie Śląskim i na Podhalu Roman Reinfuss i eksplorująca badawczo Kurpiowszczyznę Anna Kutrzeba-Pojnarowa (Braun, 2008, ss. 98-106).

Na przełomie lat sześćdziesiątych i siedemdziesiątych, odwołując się do tradycji przedwojennej etnografii i socjologii, ze szczególnym podkreśleniem wagi dokonań reprezentującego francuską szkołę socjologiczną i historyczną Jana Stanisława Bystronia, własną koncepcję regionu zaproponowat etnosocjolog Jerzy Damrosz. Wskazany badacz, widząc wzmiankowane wyżej niedostatki etnografii regionu, z której niejako intelektualnie wyrastał, postanowił je wyeliminować na powrót łącząc jej wysiłki z dokonaniami socjologów, zarówno odwołujących się do paradygmatu humanistycznego, jak i tych którzy tworzyli w ramach podejścia modernistycznego. Nazwał swoją propozycję podejściem integralnym, wyłożył ją w dziele Region i regionalizm (1987) oraz będącej jego uzupełnieniem i poszerzeniem publikacji zatytułowanej Ojczyzna i jej regiony (2007). Damrosz, wykorzystując wypracowaną przez siebie koncepcję, próbuje scharakteryzować zróżnicowanie terytorium etniczno-regionalnego Polski, wpisując je w perspektywę długiego trwania, gdzie region stanowi jedną z kluczowych kategorii opisu. Autor postuluje nawet powołanie odrębnej dyscypliny badań humanistyczno-społecznych, gdzie region będzie centralnym jej problemem. Nowa nauka miałaby nosić nazwę regiologii (Kruszewski, 2011, ss. 40-44).

Region zdaniem Damrosza jest swego rodzaju przestrzenią ograniczoną, wyodrębnianą od innych za pomocą jednej lub więcej cech swoistych pozwalających na odróżnienie go od przyległych obszarów. Mogą to być dwojakiego rodzaju typy kryteriów: „... granice linearne: (administracyjne, polityczno-państwowe) lub granice nielinearne (kulturowe i in.), dające przybliżony rozmiar przestrzenny wyodrębnionego regionu" (Damrosz, 2007, s. 47). Przestrzeń z wytyczonymi granicami musi posiadać centrum, będące rdzeniem regionu, to tam mamy do czynienia z największym natężeniem cech wyróżniających dany region. Takich punktów centralnych może być w regionie więcej niż jeden. Wokół takiego centrum (lub punktów centralnych) „... zaczyna wytwarzać się splot nici łączących interesy ludności zamieszkałej w pewnej odległości od tego ośrodka" (Damrosz, 2007, s. 48). Badacz wskazuje, że w tej konstatacji dochodzi do zintegrowania podejścia geograficznego, eksponującego przestrzeń wraz w jej charakterystykami fizycznymi i społeczno-ekonomicznymi i ujęć socjologicznych oraz etnograficznych, zaś region wyznacza terytorialny zasięg występowania jakichś cech kulturowych, ideacyjnych lub materialnych. Tym co oba te wymiary łączy jest zbiorowość regionalna integrowana więzami społecznymi i ekonomicznymi, organizująca swoje życie wokół punktów centralnych (rdzeni) regionu.

Badacz nie wprost odwołuje się do paradygmatu modernistycznego $\mathrm{w}$ badaniach regionalnych. Podobnie bowiem jak w scharakteryzowanej wcześniej perspektywie zaznacza, że region jest realnie istniejącym typem przestrzeni ograniczonej, będącej miejscem zaspakajania potrzeb i tworzenia się więzi funkcjonalnych. Charakteryzuje się hierarchiczną strukturą, z centralnymi punktami i mniej lub bardziej koncentrycznie rozchodzącymi się cechami specyficznymi, których natężenie słabnie wraz z oddalaniem się od rdzenia regionu i zbliżania się do jego granic. Damrosz jednak idzie dalej, wskazując, że taki rodzaj przestrzeni może być traktowany jako region dopiero wówczas, gdy wyżej wskazane procesy doprowadzają do wykształcenia się subiektywnych jego wyróżników. Stwierdza, że na podstawie obiektywnych uwarunkowań w dłuższej perspektywie czasowej dochodzi do wykształcenia się więzi społecznych i kulturowych wśród mieszkańców regionu, 
którzy spajani są nie tylko więziami funkcjonalnymi będącymi pochodną użytkowania i zamieszkiwania przestrzeni regionu, ale również rodzącą się w ich świadomości silną tożsamością regionalną mającą za podstawę identyfikację z podobnymi sobie mieszkańcami regionu. Odwołuje się tu do koncepcji kształtowania się poczucia odrębności wypracowanej przez Józefa Obrębskiego i Jana Stanisław Bystronia.

Regiony są bytami zanurzonymi w przeszłości, cechują się długim trwaniem, jednak, jak stwierdza badacz, jest oczywiste, że „... regiony i skupiska ludności w różnych epokach historycznych opierały się o zmienne w czasie i złożone wyznaczniki odrębności" (Damrosz, 2007, s. 91). O odrębności regionu przesądza wykształcona w procesie długiego trwania specyficzna dla niego struktura społeczna, sposoby gospodarowania a także specyficzna kultura materialna. W oparciu o tego rodzaju wyznaczniki rodzi się w zbiorowości regionalnej silna więź społeczna, której głównym elementem jest poczucie identyfikacji z członkami własnej grupy regionalnej oraz uświadamiana odrębność od innych. Tak formowane regiony stanowią trwałe elementy społeczno-kulturowego obrazu Europy, a więc także Polski. Damrosz konstatuje, że w wyniku wskazanych procesów w Polsce ukształtował się pewien stały, niewiele korygowany przez wydarzenia historyczne podział regionalny. Autor koncepcji regionu integralnego powiada, że w kraju wyszczególnić można:

a) regiony o bogatej kulturze materialnej i tradycji, gdzie zbiorowość świadoma jest własnej odmienności (Łowickie, Kurpie, Podhale, Opoczańskie);

b) regiony o bogatej kulturze materialnej i tradycji, ze zbiorowościami o niższym natężeniu tożsamości regionalnej (np. region lubelski, rzeszowski, podlaski);

c) regiony zurbanizowane, gdzie zauważalne jest zanikanie bogactwa regionalnej kultury materialnej przy relatywnie silnej regionalnej tożsamości (Górny Śląsk i Wielkopolska);

d) regiony bez ciągłości podłoża kulturowego gdzie nastąpiło zderzenie tradycji kilku grup etnograficznych (np. Dolny Śląsk, szczecińskie, Mazury).

Damrosz daje jasno do zrozumienia, że regiony kulturowe są zawsze, w szczególności w odniesieniu do Polski, częściami narodu. Mogą różnić się od niego pod wieloma względami (np. dialektem czy historią, tak jak Ślązacy czy Mazurzy różnią się od reszty Polaków), nigdy jednak nie stanowią bytu odrębnego, nawet potencjalnie. Badacz podkreśla, że kultury regionalne składają się na „... wielobarwność kultury polskiej”, są składową narodu, który przejawia się w „... różnorodności odmian lokalnych i regionalnych oraz regionalno-ludowych" (Damrosz, 2007, s. 87). Poznanie regionów służyć ma de facto lepszemu zrozumieniu narodu. Pomimo postulowanej przez Damrosza konieczności powołania odrębnej nauki o regionach, zdaje się, że badacz w rzeczywistości widzi w studiach nad regionami pomocniczą dyscyplinę w szeroko pojętym narodoznawstwie .

Przemyślenia Damrosza, z pozoru oryginalne, w rzeczywistości są przełożonymi na język socjologii etnograficznymi koncepcjami regionu wypracowanymi jeszcze w dwudziestoleciu międzywojennym. Autor opisywanej tu koncepcji próbuje łączyć podmiotową perspektywę ujmowania regionu charakterystyczną dla humanistycznej socjologii (zbiorowość regionu wraz z rozpowszechnioną w niej tożsamością regionalną) z perspektywą przedmiotową rozpowszechnioną $w$ etnografii (terytoria regionalne wyznaczane przez kryteria obiektywne takie jak charakterystyczne elementy kultury materialnej - budownictwo, strój, narzędzia gospodarskie i symbolicznej - obyczaje, sztuka ludowa, folklor, wierzenia) (Grad, 2011, s. 53). Próbuje swoją koncepcję uzupełnić o perspektywę relacyjną charakterystyczną dla geografii ekonomicznej i socjologii regionu wyrastającej z paradygmatu modernizacyjnego (region jest miejscem zaspakajania potrzeb, co rodzi sieć wewnątrzregionalnych relacji społecznych i ekonomicznych). W praktyce nie tworzy po- 
dejścia oryginalnego, odtwarza koncepcje wypracowane i stosowane wcześniej w etnografii, gdzie podstawą wyodrębnienia regionów były z reguły dawne krainy historyczno-geograficzne, w obrębie których etnografowie szukali poszczególnych grup etnograficznych. Podział na regiony u Damrosza opiera się na rekonstruowanym etnograficznie terytorialnym zróżnicowaniu dawnej kultury ludowej, gdzie lud stanowi integralną część narodu. Badacz konfrontuje obraz tego zróżnicowania z ujednoliconym wzorcem kultury narodowej (Miazga, 2010, s. 30). Tożsamość jest nadbudowana na przedmiotowym wymiarze funkcjonowania regionu, zawsze jest również elementem szerszego poczucia identyfikacji z narodem. Damrosz ignoruje zjawisko indyferentyzmu w odniesieniu do niektórych regionów (np. Śląska czy dawnych Mazur), nie zauważając różnych typów relacji więzi regionalnej z więzią narodową, które mogą kształtować się w niektórych regionach, zwłaszcza na pograniczach, o czym pisali w odniesieniu do Górnego Śląska Ossowski i Chałasiński. Autor pomimo początkowych deklaracji zupełnie ignoruje analizy regionalnych sposobów zaspakajania różnorodnych potrzeb czy tworzenia się wzorów funkcjonalnych więzi regionalnych.

Pomimo zapowiadanego przez badacza prekursorskiego charakteru podejścia integralnego w studiach nad regionem propozycja Damrosza jest w istocie kontynuacją koncepcji międzywojennych, stanowi próbę przełożenia ich na język współczesnej socjologii. Jest to jak się zdaje jedna z ostatnich próba opisu relacji pomiędzy regionami i kulturą regionów, traktowaną jako kultura ludowa, a narodem i kulturą narodową. Z tego choćby względu zasługuje na uwage. Jak powiada Zbigniew Jasiewicz, zainteresowanie tego rodzaju problematyką na obszarze polskiej etnografii, czy szerzej antropologii kulturowej, znacznie osłabło, ustępując miejsca zainteresowaniu samą kulturą narodową i jej przemianami (Jasiewicz, 2006, s. 74). Pomimo nieudanej próby utworzenia niezależnej od studiów etnicznych i narodowych subdyscypliny badań regionalnych, istotnym w przedstawionej tu koncepcji wydaje się wskazanie na konieczność połączenia wymiaru subiektywnego, obiektywnego i relacyjnego regionu.

\section{REGION W PERSPEKTYWIE KONSTRUKTYWNEGO INSTYTUCJONALIZMU}

W ostatnich latach w polskiej socjologii odnotować można coraz większe zainteresowanie teoriami socjologicznymi, które przełożone na język socjologii regionu pozwalają na wprowadzenie do koncepcji regionu wymiaru dynamicznego przez uwypuklenie relacyjności oraz próby łącznej analizy wymiarów tożsamościowych i strukturalnych regionu.

Co więcej, nie wyrastają one z tradycji humanistycznej socjologii Stanisława Ossowskiego, która jak starałem się wskazać zdominowała socjologiczne badania regionów w Polsce. Są to także udane próby przezwyciężenia przestrzenno-obiektywistycznego redukcjonizmu perspektywy modernizacyjnej. Warto tu wspomnieć o pracy Borysa Cymbrowskiego, który odwołuje się do strukturalistycznego konstruktywizmu Pierre'a Bourdieu, analizując regionalną problematykę władzy w województwach śląskim i opolskim. Badacz wykorzystuje teorię pól francuskiego teoretyka do analizy pól władzy w badanych przez siebie województwach. Region jako pole władzy oznaczać będzie aktorów społecznych, jednostkowych i zbiorowych, powiązanych ze sobą wspólnotą celów i dążeń, rywalizujących w tym polu o władzę, wykorzystujących dostępne w nim zasady i kapitały (Cymbrowski, 2005). Pamiętać jednak należy, że to tylko jeden w wielu wymiarów 
funkcjonowania regionu. Wartą uwagi jest również praca pod tytułem Region tradycyjny w państwie unitarnym $w$ dobie globalizacji autorstwa krakowskiego socjologa Andrzeja Bukowskiego, który także podkreśla relacyjny i dynamiczny charakter tworzenia się i funkcjonowania regionów. W swoich studiach nad Małopolską jako regionem, badacz odwołuje się do konstruktywnego instytucjonalizmu w jego ewolucyjnej odmianie (Bukowski, 2011).

W moim mniemaniu duży potencjał heurystyczny niosą ze sobą studia nad regionem inspirowane perspektywą teoretyczną prezentowaną przez fińskiego badacza regionów Anssi Paasi'ego (2009). W większości naukowych prób opisu takiego zjawiska jakim jest region wskazuje się na trzy jego elementy, są to przestrzeń, zbiorowość, z jej specyfiką społeczno-kulturową oraz ustalone dla tej przestrzeni i zbiorowości stosunki władzy (Miazga, 2010, s. 11). Passi nie poprzestaje na charakterystyce wymienionych elementów regionu, wskazuje na wielorakie relacje, jakie pomiędzy nimi zachodzą, przeciwstawiając dominacji statycznych lub redukcjonistycznych podejść perspektywę procesualną (Schrijver, 2006, s. 22). Region to dynamiczna społeczno-przestrzenne konstrukcja podlegająca zmianom, tworzona w procesie rozciągniętym pomiędzy przeszłością, teraźniejszością i projektowaną przez regionalne jednostki i instytucje w oparciu o przeszłość przyszłością. Jest on „... społeczno-przestrzennym procesem w efekcie którego, pewne jednostki terytorialne pojawiają się jako elementy zbiorowości, kształtują się i przejawiają w różnych sferach społecznych działań i zbiorowych tożsamości" (Paasi, 1986, s. 121). W koncepcji fińskiego badacza regiony nie są pasywnym przedmiotem czy instrumentem działania społecznego, ani funkcjonującym ponadindywidualnie bytem istniejącym ponad sferą ludzkich działań zupełnie niezależnie. Konstruowanie regionów to sekwencja praktyk mających na celu społeczne zorganizowanie przestrzeni. Proces ów zachodzi w różnych skalach czasowych i na różnych poziomach regionalnych struktur społecznych, gospodarczych i politycznych oraz w różnych typach społecznych grup regionalnych aktorów (Paasi, 2001, s. 16). Proces nie jest ograniczony do zorganizowanej zbiorowości terytorialnej zamieszkującej przestrzeń jakiejś szczególnej wielkości, czy do nowych regionów pojawiających się jako rezultat wspomnianego procesu w nieodległej przeszłości, ale również odnosi się do powstawania, rozwoju i ewentualnego zanikania tradycyjnych regionów kulturowych.

Regiony nie są po prostu historycznie czy naturalnie daną jednostką terytorialną będącą ramą funkcjonowania jakiejś mniej lub bardziej zorganizowanej zbiorowości społecznej, są „... społecznymi, politycznymi i ekonomicznymi konstruktami [...], które mogą być słabo obecne w życiu codziennym zwykłych ludzi, [...] są one reprezentacjami publicznymi, które dosłownie zajmują miejsce w sferze dyskursów" (Paasi, 1999, s. 217). Region nie jest więc jakimś typem wspólnoty wyobrażonej czy też korelatem zbiorowości regionalnej spajanej wspólną tożsamością, to społeczno-przestrzenna konstelacja, w obrębie której „... działa władza, złożona z obrazów, dyskursów, strategii oraz innych praktyk społecznych, politycznych, ekonomicznych, administracyjnych i kulturowych, które przeniknięte są stosunkami władzy" (Paasi, 1991, ss. 243-244). Tożsamość mieszkańców regionu i więzi społeczne integrujące zbiorowość łączące ją z narodem, bądź przeciwnie rozgraniczające te dwa typy dużych grup społecznych, to jeden z wielu elementów regionu.

Region powstaje w procesie wielofazowej instytucjonalizacji. Po pierwsze wyłania się jego rama przestrzenna (faza terytorialna) oraz powstają i lokują się $w$ tej przestrzeni instytucje (faza instytucjonalna), które obejmują swoim władztwem formalnym bądź nieformalnym zbiorowość zamieszkującą daną przestrzeń. Następnie w celu potwierdzenia realności istnienia regionu, legitymizacji prawomocności swojego władztwa instytu- 
cje wykorzystują istniejące bądź tworzą na nowo mity, symbole, opowieści, które stając się częścią regionalnego dyskursu publicznego zaczynają oddziaływać na świadomość jednostek (faza symboliczna). Symboliczny obraz regionu, Passi nazywa go tożsamością regionu, narzucany dyskursywnie staje się częścią tożsamości ludzi mieszkających w regionie, którzy nie pozostają bierni i poprzez swoje wyobrażenia oraz podejmowane działania społeczne wpływają na jego kształt. W złożonej grze polegającej na kształtowaniu wyobrażeń o regionie, jaka toczy się pomiędzy regionalnymi aktorami, dochodzi do reprodukowania regionu (faza pełnej instytucjonalizacji). Działania instytucji formalnych, których przejawami są np. strategie rozwojowe, plany działania, dokumenty planistyczne, napotykają reakcję aprobującą bądź odrzucenie ze strony regionalnej zbiorowości. Owa gra, która toczy się w dużej mierze dyskursywnie, tworząc tożsamość regionu i regionalną tożsamość mieszkańców odbywa się w konkretnych uwarunkowaniach ekonomicznych i politycznych, dodatkowo przenikana jest relacjami z państwem oraz zjawiskami ponadpaństwowymi.

Na uwagę zasługują badania Anny Gąsior-Niemiec, która odwołuje się w swoich publikacjach do krótko wyłożonej wyżej teorii instytucjonalizacji regionów. Badaczka w publikacji Galicja na Podkarpaciu, czyli o lokalnej niefortunności tradycji wykorzystuje teorię Ansii Paasiego do analiz procesów odgórnego instytucjonalizowania Galicji jako regionu (Gąsior-Niemiec, 2006). Próbą połączenia teorii instytucjonalizacji regionów z perspektywą humanistyczną są studia nad kształtowaniem się regionu na Warmii i Mazurach od zakończenia II wojny światowej do współczesności opublikowane przez autora niniejszego tekstu w książce noszącej tytuł Postmigracyjne tworzenie tożsamości regionalnej. W wyniku przyznania Polsce po II wojnie światowej południowych powiatów Prus Wschodnich i całkowitej niemalże wymiany ludności na tych terenach wytworzyła się sytuacja swoistego społecznego laboratorium, którego obserwacja pozwoliła na przetestowanie teorii instytucjonalizowania się regionów. W nowym województwie olsztyńskim zamieszkała nowa zbiorowość złożona z przedstawicieli różnych grup regionalnych, etnicznych i narodowych. Władze nowo wyznaczonej jednostki terytorialnej przez swoje działania formalne i nieformalne zaczęły dążyć do integrowania nowej ludności i legitymizowania własnego istnienia w nowym województwie. Wykorzystując specyficznie przetworzone mity i symbole ludności autochtonicznej (Warmiaków i Mazurów), łączyły je z własną mitologią (mit powrotu na Ziemie Odzyskane) i narzucały przez dyskurs publiczny regionalnej zbiorowości. Z czasem w kolejnych pokoleniach wytworzyła się w świadomości ludzi regionalna tożsamość i specyficzny obraz regionu, korygowany o mity wielokulturowości regionu po przełomie roku 1989. Po kilkudziesięciu latach doszło do instytucjonalizacji regionu Warmii i Mazur, który reprodukowany jest w regionalnej grze pomiędzy aktorami regionalnymi, przejawia się w wyobrażeniach, tożsamości i działaniach społecznych.

We wskazanych badaniach odchodzi się od redukcjonizmu humanistycznego każącego ujmować region jako odmianę zlokalizowanej przestrzennie zbiorowości spajanej wspólną tożsamością, która z reguły stanowi element większej zbiorowości narodowej. Nie sprowadza regionu również do przestrzennie zdywersyfikowanej kultury ludowej, jak czyni się w etnografii regionu. Nie redukuje też przestrzeni do zestawu obiektywnie obserwowalnych i dających się zliczyć charakterystyk społeczno-gospodarczych jakiegoś terytorium, co stanowiło cechę marksistowsko-modernizacyjnej socjologii regionu. Wskazuje się tu na ważność przestrzeni regionu, jako faktycznej i symbolicznej sceny, na której realizowane są społeczne praktyki budowania formalnych i nieformalnych instytucji oraz symboli i wyobrażeń, które budują region tylko wówczas kiedy wchodzą ze sobą w wielokrotnie 
złożone relacje mające charakter procesu instytucjonalizacji. Region jest tu kolektywną konstrukcją, dynamiczną i zmienną, ukształtowaną w dużej mierze przez wykształcone w przeszłości zasady, instytucje, obyczaje. Region to odniesiony do określonej przestrzeni proces tworzenia instytucji, poprzez „... przekształcanie instytucji już przyswojonych, z drugiej poprzez adaptowanie się do zewnętrznych ram i kontekstów instytucjonalnych" (Bukowski, 2011, s. 9). To co najważniejsze w charakteryzowanej tu perspektywie, to możliwość wypracowania socjologii regionu, która stanowiła by rzeczywiście autonomiczną subdyscyplinę wyzwoloną spod dominującego wpływy socjologii etniczności i narodu lub ekonomii rozwoju regionalnego i studiów etnograficznych. Zwraca się tu uwage zarówno na eksponowane w socjologii humanistycznej więzi społeczne i wagę tożsamości, oraz podkreślane w perspektywie modernizacyjnej uwarunkowania strukturalne oraz łączące oba te wymiary złożone relacje, które w dynamicznym procesie instytucjonalizacji prowadzą do powstawania i reprodukowanie się regionu.

\section{ZAKOŃCZENIE}

W prezentowanym tekście wykazany został dominujący wpływ humanistycznej koncepcji regionu-ojczyzny prywatnej na studia regionalne w polskiej socjologii. Podejmowane, niezwykle ciekawe i wartościowe, próby stworzenia nowych podejść w wielu przypadkach były niewielką tylko korektą w ramach podejścia dominującego. Humanistyczne ujmowanie regionu jako ojczyzny prywatnej zamieszkałej przez spajaną wspólną tożsamością i więziami regionalnymi zbiorowość regionalną wyrosło ze studiów nad etnicznością i narodami faktycznie podporządkowując studia regionalne tym subdyscyplinom. Próba zerwanie związku z socjologią narodu podjęta w perspektywie modernizacyjnej zubożyła teoretycznie socjologiczne studia regionalne przez wyeliminowanie z obszaru dociekań eksponowanych w ujęciu humanistycznym świadomościowych wymiarów funkcjonowania regionu. Niemniej jednak wskazano na konieczność uwzględnienia problematyki uwarunkowań strukturalnych w badaniu regionów. W podejściu integralnym wskazano na konieczność widzenia w regionie splotu uwarunkowań strukturalnych i świadomościowych jakie funkcjonują w regionach, w których cały czas widziano składowe narodów. Ów splot wyrażający się w relacyjności regionu, czyli procesie jego kształtowania się i reprodukowania, który polega na wzajemnym oddziaływaniu instytucji formalnych i nieformalnych w regionie, zbiorowości i różnych typów regionalnych aktorów, wizerunków regionu i tożsamości jednostek odnoszonych do niego ma charakter procesu instytucjonalizacji. Teoretyczna perspektywa instytucjonalizacji regionu pozwala na wyemancypowanie się studiów nad regionem spod dominującego wpływu studiów nad etnicznością i narodem nie rezygnując z wartościowych jej względem regionów ustaleń.

\section{BIBLIOGRAFIA}

Aleksandrowicz, S. (1993). Różne pojęcia historii regionalnej i możliwości jej uprawiania. W K. Handke (Red.), Region, regionalizm - pojęcia i rzeczywistość (ss. 37-48). Warszawa: SOW. 
Bartkowski, J. (2003). Tradycja i polityka: Wpływ tradycji kulturowych polskich regionów na współczesne zachowania społeczne i polityczne. Warszawa: ŻAK.

Bartkowski, J. (2005). Narodowe, lokalne i europejskie identyfikacje elit europejskich. W M. Malikowski \& D. Wojakowski (Red.), Granice i pogranicza nowej Unii Europejskiej (ss. 241-258). Kraków: UJ.

Braun, K. (2008). Anna Kutrzeba-Pojnarowa (1913-1993). Rocznik Mazowiecki, 20, 98-106.

Bukowski, A. (2011). Region tradycyjny w unitarnym państwie $w$ dobie globalizacji. Kraków: UJ.

Burszta, J. (1967). Region i regionalne monografie etnograficzne. Lud, 51(cz. 2), 599-614.

Burszta, J. (1974). Kultura ludowa - kultura narodowa: Szkice i rozprawy. Warszawa: LSW.

Burszta, J. (1983). Lud - naród - kultura. W A. Kłoskowska (Red.), Naród - kultura - osobowość (ss. 39-50). Wrocław: Ossolineum.

Bystroń, S. J. (1925). Ugrupowania etniczne ludu polskiego. Kraków: Orbis.

Chałasiński, J. (1935). Antagonizm polsko-niemiecki w osadzie fabrycznej "Kopalnia" na Górnym Śląsku. Warszawa: LSW.

Chałasiński, J. (1968). Kultura i naród: Szkice i studia. Warszawa: LSW.

Chojnicki, Z. (1993). Region i regionalizm w geografii. W K. Handke (Red.), Region, regionalizm - pojęcia i rzeczywistość (ss. 13-36). Warszawa: SOW.

Chojnicki, Z. (1996). Region w ujęciu geograficzno-systemowym. W T. Czyż (Red.), Podstawy regionalizacji geograficznej (ss. 7-43). Poznań: Bogucki Wydawnictwo Naukowe.

Chudziński, E. (2013). Regionalizm: Idee - Iudzie - instytucje. Warszawa: Mazowiecka Oficyna Wydawnicza.

Ciechocińska, M. (1976). Socjologia regionalna w Polsce na tle światowym. Studia Socjologiczne, (4), 197-226.

Ciechocińska, M. (1978). Problematyka warunków życia w ujęciach socjologii regionalnej. Studia Socjologiczne, (4), 178-201.

Ciechocińska, M. (1983). Region jako teren badań socjologicznych. Studia Socjologiczne, (3), 61-76.

Cymbrowski, B. (2005). Regionalne pole władzy: Transformacja w Polsce a układy władz w regionach na przykładzie województw śląskiego i opolskiego. W K. Bondyra, M. S. Szczepański, \& P. Śliwa (Red.), Państwo, samorząd i społeczeństwo lokalne (ss. 189-210). Poznań: WSB.

Damrosz, J. (1987). Region i regionalizm: Studium dyscyplinarne. Warszawa: Instytut Kultury.

Damrosz, J. (2007). Ojczyzna i jej regiony. Płock, Warszawa: Towarzystwo Naukowe Płockie. Dziewoński, K. (1967). Teoria regionu ekonomicznego. Przegląd Geograficzny, (1), 35-50.

Engelking, A. (2006). Józef Obrębski - etnolog i socjolog warszawski. Sprawy Narodowościowe, (29), 91-106.

Engelking, A. (2012). Kazimierz Moszyński i Józef Obrębski: nauczyciel i uczeń. Lud, 96, 139-156.

Gąsior-Niemiec, A. (2006). Galicja na Podkarpaciu, czyli o lokalnej niefortunności tradycji. W J. Kurczewska (Red.), Oblicza lokalności: Różnorodność miejsc i czasu (ss. 390412). Warszawa: IFiS PAN.

Gołębiowski, Ł. (1830). Lud polski, jego zwyczaje, zabobony. Warszawa: Drukarnia A. Gałęzowskiego i spótki.

Gorlach, K. (2004). Socjologia obszarów wiejskich. Warszawa: Scholar.

Grad, J. (2011). Współczesny sens regionalizmu. Sensus Historiae, (1), 51-68. 
Handke, K. (1993). Pojęcie regionu a symbolika środka. W K. Handke (Red.), Region, regionalizm - pojęcia i rzeczywistość (ss. 105-120). Warszawa: SOW.

Jałowiecki, B. (1993). Kwestia regionalna. W G. Gorzelak \& B. Jałowiecki (Red.), Czy Polska będzie państwem regionalnym (ss. 11-43). Warszawa: UW.

Jasiewicz, Z. (2006). Etnologia polska: Między etnografią a antropologią kulturową. Nauka, (2), 65-80.

Kłoskowska, A. (2005). Kultury narodowe u korzeni. Warszawa: PWN.

Kopczyńska-Jaworska, B. (1998). Etnografia a zagadnienia regionu. W S. Bednarek (Red.), Czym jest regionalizm? (ss. 60-72). Wrocław, Ciechanów: RKRTK.

Kruszewski, Z. (2011). Jerzy Damrosz, „Ojczyzna i jej regiony”. Towarzystwo Naukowe Płockie, Szkoła Wyższa im. Pawła Włodkowica w Płocku, Płock-Warszawa 2007 [Recenzja]. Notatki Płockie, 56(3), 40-44.

Kubiak, H. (2007). U progu ery postwestfalskiej. Kraków: Universitas.

Kwilecki, A. (1992). Region i badania regionalne w perspektywie socjologii. Ruch Prawniczy, Ekonomiczny i Socjologiczny, (2), 37-48.

Łuczeczko, P. (2011). Socjologiczne badania nad kulturą a nauki etnologiczne: Historia romansów i rozstań oraz jej konsekwencje. Roczniki Historii Socjologii, (1), 57-68.

Malikowski, M. (1998). Zbiorowości terytorialne. W Z. Krawczyk \& K. Sowa (Red.), Socjologia w Polsce (ss. 78-106). Rzeszów: WSP.

McMichael, M. (1998). Globalizacja: mity i realia. W K. Gorlach (Red.), Socjologia wsi w Ameryce Pótnocnej (ss. 285-310). Toruń: UMK.

Miazga, M. (2010). Z zagadnień socjologii regionu. Lublin: WSAP.

Moszyński, K. (1934). Kultura ludowa Słowian. Kraków: Gebethner.

Nowakowski, S. (1957). Adaptacja ludności na Śląsku Opolskim. Poznań: Instytut Zachodni.

Obracht-Prondzyński, C. (2002). Kaszubi - między dyskryminacją a regionalną podmiotowością. Gdańsk: Instytut Kaszubski.

Obrębski, J. (1936). Problem grup etnicznych w etnologii i jego socjologiczne ujęcie. Przegląd Socjologiczny, 4(1-2), 177-195.

Ossowski, S. (1967). Zagadnienie więzi regionalnej i więzi narodowej na Śląsku Opolskim. W S. Ossowski, Dzieła (T. 3, ss. 251-300). Warszawa: PWN.

Ossowski, S. (1983). O osobliwościach nauk społecznych. Warszawa: PWN.

Ossowski, S. (1984). O ojczyźnie i narodzie. Warszawa: PWN.

Paasi, A. (1986). Institutionalization of regions: A theoretical framework for understanding the emergence of regions and the constitution regional identity. Fennia, (164), 105-146.

Paasi, A. (1991). Deconstructing regions: Notes on the scales of spatial life. Environment and Planning A, 23(2), 239-256. http://doi.org/10.1068/a230239

Paasi, A. (1999). The Finnish-Russian border in a world of de-territorialisation. Berlin: Springer.

Paasi, A. (2001). Europe as a social process and discourse: Considerations of place, boundaries and identity. European Urban and Regional Studies, 8(1), 7-28. http://doi. org/10.1177/096977640100800102

Paasi, A. (2009). The resurgence of the 'Region' and 'Regional Identity': Theoretical perspectives and empirical observations on regional dynamics in Europe. Review of International Studies, 35(S1), 121-146. http://doi.org/10.1017/S0260210509008456

Piotrowski, M. (1999). Region i tożsamość regionalna w świetle badań empirycznych. W A. Matczak (Red.), Badania nad tożsamością regionalną (ss. 54-60). Łódź, Ciechanów: KODRTK. 
Poniedziałek, J. (2011). Postmigracyjne tworzenie tożsamości regionalnej. Toruń: A. Marszatek.

Posern-Zieliński, A. (1995). Problematyka etniczna w badaniach etnologicznych i antropologicznych. Lud, 78, 293-316.

Posern-Zieliński, A. (2005). Tożsamość a terytorium: Perspektywa antropologiczna. Przegląd Zachodni, (3), 3-20.

Rybicki, P. (1983). Naród i państwo. W A. Kłoskowska (Red.), Naród - kultura - osobowość (ss. 487-502). Wrocław: Ossolineum.

Rykiel, Z. (2008). Koncepcja przestrzeni i teorie regionu a wzorce uprawiania socjologii. W Z. Rykiel (Red.), Nowa przestrzeń społeczna w badaniach socjologicznych (ss. 1339). Rzeszów: Uniwersytet Rzeszowski.

Rykiel, Z. (2009). Podkarpacie jako region - podstawy teoretyczne. W A. Tuziak \& B. Tuziak (Red.), Regionalny wymiar procesów transformacyjnych (ss. 13-28). Warszawa: Scholar. Rykiel, Z. (2011). Teorie regionu społecznego. W M. S. Szczepański, A. Śliz, R. Geisler, \& B. Cymbrowski (Red.), Socjologia regionu i społeczności lokalnych (ss. 67-110). Opole: Wydawnictwo Uniwersytetu Opolskiego.

Sadowski, A. (2006). Wielokulturowe społeczeństwo regionalne. W B. Jałowiecki \& W. Łukowski (Red.), Społeczności lokalne: teraźniejszość i przyszłość (ss. 129-144). Warszawa: Scholar.

Sagan, I. (2011). Współczesne studia regionalne. W M. S. Szczepański, A. Śliz, R. Geisler, \& B. Cymbrowski (Red.), Socjologia regionu i społeczności lokalnych (ss. 35-48). Opole: Wydawnictwo Uniwersytetu Opolskiego.

Sakson, A. (2006). Tożsamość lokalna i regionalna współczesnych mieszkańców byłych Prus Wschodnich. Przegląd Zachodni, (1), 201-224.

Schrijver, F. (2006). Regionalism after regionalization: Spain, France and the United Kingdom. Amsterdam: Amsterdam University Press.

Sekuła, A. E. (2009). Po co Ślązakom potrzebny jest naród? Warszawa: WAiP.

Skorowski, H. (1999). Europa regionu. Warszawa: ATK.

Sołdra-Gwiżdż, T. (2014). Stosunki etniczne w badaniach Instytutu Śląskiego z perspektywy jego 80-lecia: Ethnic relations in the studies of Silesian Institute from the perspective of its eighty years of existence. Studia Humanistyczne AGH, 13(3), 101-113. http:// doi.org/10.7494/human.2014.13.3.101

Starosta, P. (1999). Tożsamość regionalna w perspektywie socjologicznej. W A. Matczak (Red.), Badania nad tożsamością regionalną (ss. 40-53). Łódź, Ciechanów: KODRTK.

Szczepański, J. (1973). Zmiany społeczeństwa polskiego pod wpływem uprzemysłowienia. Warszawa: Instytut Wydawniczy CRZZ.

Tomaszewski, K. (2007). Regiony w procesie integracji europejskiej. Warszawa: Wolters Kluwer.

Turowski, J. (1995). Socjologia wsi i rolnictwa. Lublin: KUL.

Węglarz, S. (1997). Tutejsi i inni. Łódź: Ut.

Wieruszewska, M. (2008). Tożsamość kulturowa wsi: Kwestie i zobowiązania. Przegląd Humanistyczny, (6), 31-46.

Wierzbicki, T. Z, \& Bertrand, L. A. (1970). Socjologia wsi w Stanach Zjednoczonych: Stan i tendencje rozwojowe. Wrocław: Ossolineum.

Wrzesiński, W. (1999). Region i tożsamość regionalna w świetle badań historycznych. W A. Matczak (Red.), Badania nad tożsamością regionalną (ss. 18-30). Łódź, Ciechanów: KODRTK. 
Ziółkowski, J. (1972). Socjologia i planowanie społeczne. Warszawa: PWN.

Znaniecki, F. (1990). Wspótczesne narody. Warszawa: PWN.

Znaniecki, F. (2001). Ludzie teraźniejsi a cywilizacja przyszłości. Warszawa: PWN.

Znaniecki, F. (2003). Ludzie teraźniejsi a cywilizacja przyszłości. Warszawa: PWN.

Żelazny, W. (1998). Modele integracji europejskiej: Nawigacja pomiędzy Europą państw a Europą regionów. W P. Buczkowski, K. Bondyra, \& P. Śliwa (Red.), Jaka Europa? Regionalizacja a integracja (ss. 33-53). Poznań: WSB. 